using a riding model, 361 parameters, $R 1$ for 6670 reflections with $F_{0}>4 \pi\left(F_{0}\right)$ was 0.0444 , and 0.0509 for all data, $w R 2$ for all data was 0.1325 , GOF $=1.061$ cf. $[11 \mathrm{~b}]$.

[4] A. G. Brook, J. W. Harris, J. Lennon. M. ElSheikh, J. Am. Chem. Soc. 1979 101. 83: A. G. Brook, K. M. Baines, Adv. Organomet. Chem. 1986, 25, 26.

[5] J. Ohshita, Y. Masaoka, M. Ishikawa, Organometallics 1991, 10, 3775.

[6] G. Raabe, J. Micht in The Chemistry of Organic Silicon Compounds (Eds.: S Patai, Z. Rappoport). Wiley, New York, 1989, p. 1100.

[7] A. G. Brook, H.-J. Wessely, Organometallics 1985. 4, 1487.

[8] D. B. Puranik. M. P. Johnson. M. J. Fink, J. Chem. Soc. Chem. Commun. 1989 706.

[9] A. G. Brook, S. C. Nyburg, W. F. Reynolds, Y. C. Poon, Y.-M chang. J.-S. Lee J. P. Picard J. Am. Chem. Soc. 1979, 101, 6750; D. Bravo-Zhivotovskii, V Braude, A. Stanger, M. Kapon. Y. Apeloig. Organometallics 1992, 11. 2326.

[10] K. M. Baines. A. G. Brook, Organometallics 1987. 6, 692.

[11] a) Crystal structure analysis of 8 : space group $P 2_{1} / c, a=1026.6(2), b=$ $2055.7(4), c=1836.7(4) \mathrm{pm} . \quad \beta=97.14(3) . \quad \gamma=3.8461 \mathrm{~nm}^{3}, \quad Z=4 . \quad \mu=$ $0.24 \mathrm{~mm}^{-1}\left(\mathrm{Mo}_{\mathrm{K} s}\right) .7558$ measured reflections, $2 \theta_{\max }=52$, structure solution by direct methods [13]. 7450 reflections used for refinement on $F^{2}$ [14]. The $\mathrm{Si}$ and $\mathrm{C}$ atoms were refined anisotropically, $\mathrm{H}$ atoms were calculated from electron density difference maps and refined by using a riding model, 343 parameters. $R 1$ for 4246 reflections with $F_{0}>4 \sigma\left(F_{0}\right)$ was 0.0672 , and 0.1347 for all data, $1 R 2$ for all data was $0.1903, G O F=1.040$. b) Further details of the crystal structure investigation may be obtained from the Fachinformationszen. trum Karlsruhe. D-76344 Eggenstein-Leopoldshafen (FRG) on quoting the depository number CSD-58237.

[12] N. Wiberg, J. Organomet. Chem. 1984, 273, 141.

[13] G. M. Sheldrick. SHELXS 86. Universitat Götingen, 1986

[14] G. M. Sheldrick. SHELXL-93, Universität Göttingen, 1993

\section{An Efficient Access to Organocerium(Iv) Complexes: Synthesis and Structure of Bis|1,3,6-tris(trimethylsilyl)cyclo- octatetraenejcerium(IV)***}

Ulrike Kilimann, Regine Herbst-Irmer, Dietmar Stalke, and Frank T. Edelmann*

Dedicated to Professor Wolfgang Lütke

on the occasion of his 75 th birthday

The synthesis of stable organometallic compounds containing tetravalent cerium is one of the challenges in the field of preparative organo-f-element chemistry. ${ }^{[1]}$ The main reason why numerous attempts at the synthesis of organocerium(IV) complexes have failed is the strong oxidizing effect of the cerium(iv) ion $\left(E^{0}\right.$ for $\mathrm{Ce}^{3+} / \mathrm{Ce}^{4+}$ in $\mathrm{HCl}:+1.28 \mathrm{~V}$; in $\left.8 \mathrm{M} \mathrm{HClO}_{4}:+1.87 \mathrm{~V}^{[2]}\right)$. Thus, in reactions with organometallic reagents such as $\mathrm{NaC}_{5} \mathrm{H}_{5}$, the cerium(IV) reagents $\left(\mathrm{NH}_{4}\right)_{2}\left[\mathrm{Ce}\left(\mathrm{NO}_{3}\right)_{6}\right]$ or [py $\mathrm{H}_{2}\left[\mathrm{CeCl}_{6}\right]$ (pyH = pyridinium cation) are reduced without exception to cerium(III) products. A series of complexes of the type $\left[\left(\mathrm{C}_{5} \mathrm{H}_{5}\right)_{3} \mathrm{CeX}\right]$ and $\left[\left(\mathrm{C}_{9} \mathrm{H}_{7}\right)_{2} \mathrm{CeX}_{2}\right]\left(\mathrm{X}=\mathrm{H}, \mathrm{BH}_{4}, \mathrm{Cl}, \mathrm{N}_{3}\right.$, $\mathrm{CN}, \mathrm{NCO}, \mathrm{NO}_{2}, \mathrm{NO}_{3}, \mathrm{OR}, \mathrm{O}_{2} \mathrm{CR}, \mathrm{SR}, \mathrm{NH}_{2}$, alkyl, aryl) described in the $1970 \mathrm{~s}^{[3-6]}$ were all found to have been wrongly characterized. ["] Also, for " $\left[\left(\mathrm{C}_{5} \mathrm{H}_{5}\right)_{4} \mathrm{Ce}\right]$ "[3] it was demonstrated that this compound was in fact $\left[\left(\mathrm{C}_{5} \mathrm{H}_{5}\right)_{3} \mathrm{Ce}(\mathrm{thf})\right]^{\left[{ }^{[7]} \mathrm{Bis}(\text { cyclo- }\right.}$ octatetraene)cerium(IV) (1), also known as bis([8]annulene)-

$\left[\mathrm{Ce}\left(\eta^{8}-\mathrm{C}_{8} \mathrm{H}_{8}\right)_{2}\right] \quad \mathbf{1}$

$\left[{ }^{*}\right]$ Priv.-Doz. Dr. F. T. Edelmann, Dr. U. Kilimann, Dr. R. Herbst-Irmer Priv.-Doz. Dr. D. Stalke

Institut für Anorganische Chemie der Universität Tammannstrasse 4, D-37077 Göttingen (FRG) Telefax: Int. code + (551)39-3373

$\left[{ }^{* *}\right]$ This work was supported by the Fonds der Chemischen Industrie, by the Deutsche Forschungsgemeinschaft, and by the BASF AG
cerium(IV) or "cerocene", which is of considerable theoretical interest, ${ }^{[8,9]}$ and its $1,1^{\prime}$-dimethyl derivative $\left[\mathrm{Ce}\left(\mathrm{C}_{8} \mathrm{H}_{7} \mathrm{Me}\right)_{2}\right]^{[10]}$ are among the few fully characterized organocerium(IV) complexes. Complex 1 was discovered in 1976 by Cesca et al :11] $^{11]}$ however, because of its pyrophoric nature and its poor solubility in organic solvents, unsubstituted $\mathbf{1}$ is not very attractive for reactivity studies. We describe here an efficient entry to soluble bis(cyclooctatetraene)cerium(IV) complexes, which for the first time allows an extensive study of this interesting class of compounds.

For the reasons mentioned above the controlled oxidation of cerium(III) precursors appeared to be a more suitable route for the synthesis of new cerium(IV) complexes than starting from $\left(\mathrm{NH}_{4}\right)_{2}\left[\mathrm{Ce}\left(\mathrm{NO}_{3}\right)_{6}\right]$ or $[\mathrm{pyH}]_{2}\left[\mathrm{CeCl}_{6}\right]$. In our synthesis concept substituted cyclooctatetraene ligands should sterically shield the cerium atom and thus protect it from decomposition reactions. As in many cyclopentadienyl complexes, for example those with 1,3-bis(trimethylsily])cyclopentadienyl ligands, ${ }^{[12,13]}$ bulky trimethylsilyl substituents should be particularly suitable for this purpose.

Following a suggestion by Cloke et al., ${ }^{[14]}$ initially the dianion of 1,4-bis(trimethylsilyl)cyclooctatetraene was prepared. Its lithium salt 3 is readily accessible by metalation of $1,4-$ bis(trimethylsilyl)cyclooctatriene (2) with $n$-butyllithium. ${ }^{\text {[13] }}$ The starting material 2 can be obtained in a one-pot reaction from 1,5-cyclooctadiene. ${ }^{[15]}$ The reaction of 3 with anhydrous cerium trichloride in a molar ratio of $2: 1$ leads to the bright green anionic sandwich complex 4 , which because of its extreme sensitivity to oxidation was not isolated but immediately converted to the neutral cerium(Iv) derivative. The desired oxidation to yield 5 occurs smoothly and under mild conditions with

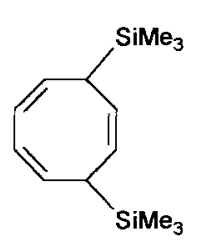

2

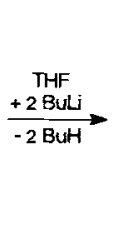

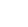

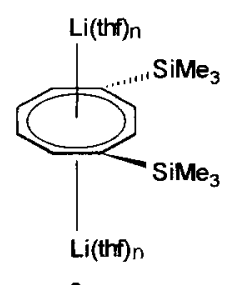

3

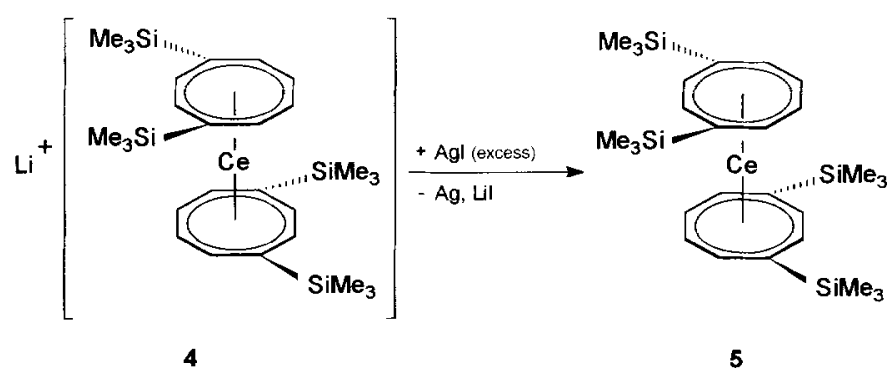

an excess of silver iodide as oxidizing agent. Bis[1,4-bis(trimethylsilyl)cyclooctatetraene]cerium(Iv) (5) is the first readily accessible derivative of 1 , which is sufficiently soluble to allow reactivity studies. Spectroscopically pure, diamagnetic 5 is obtained as a deep purple oil, which thermally decomposes only above $226^{\circ} \mathrm{C}$. In contrast to the pyrophoric parent compound $1{ }^{[11]}$ compound 5 can be handled in air for short periods of time. In the EI mass spectrum the molecular ion appears as the highest mass peak with $6 \%$ relative intensity.

The synthesis of a crystalline derivative of $\mathbf{1}$ was achieved by using the new sterically demanding ligand 1,3,6$\left(\mathrm{Me}_{3} \mathrm{Si}\right)_{3} \mathrm{C}_{8} \mathrm{H}_{5}^{2-}$. Compound 3 prepared in situ reacted with two 
equivalents of chlorotrimethylsilane in $\mathrm{Et}_{2} \mathrm{O} / \mathrm{THF}$ selectively to give 1,3,6,6-tetrakis(trimethylsilyl)cyclooctatriene $(6),{ }^{[15]}$ which can be isolated as colorless, sublimable needles in $52 \%$ yield. The substitution pattern of 6 is confirmed unequivocally by the NMR data. The presence of two trimethylsilyl groups on one carbon atom of the cycle initially made the desired derivatization to give the substituted cyclooctatetraene dianion appear impossible (1,2,4,4-tetrakis(trimethylsilyl)cyclopentadiene cannot be metalated at the cyclopentadiene ring ${ }^{[16]}$.
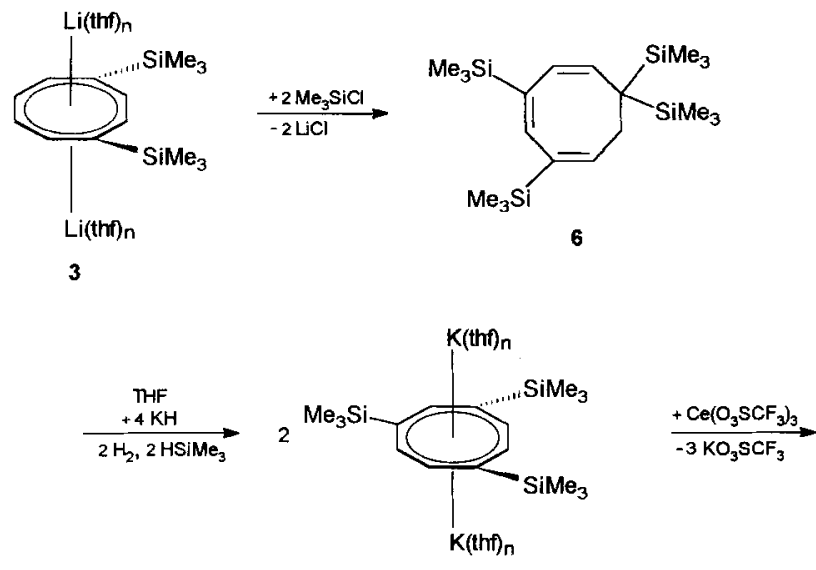

7

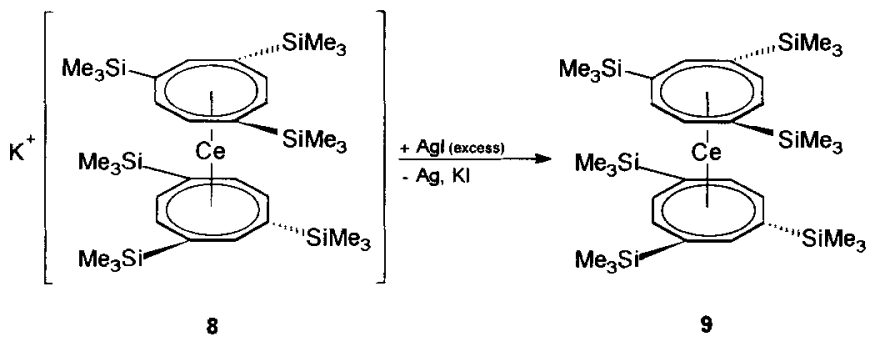

Indeed, $\mathbf{6}$ proved to be completely inert towards $n$-butyllithium. Surprisingly, the metalation was achieved with potassium hydride; however, a notable reaction was only observed in boiling THF. In addition to the expected deprotonation, a trimethylsilyl group is eliminated in the form of trimethylsilane. This leads to the dipotassium salt of the 1,3,6-tris(trimethylsilyl)cyclooctatetraene dianion $7(37 \%)$. The latter is isolated as a colorless, microcrystalline powder of the composition $\left[\mathrm{K}_{2}(\mathrm{thf})_{3}\right]\left[\mathrm{C}_{8} \mathrm{H}_{5}\left(\mathrm{SiMe}_{3}\right)_{3}\right]$ and spectroscopically characterized. Subsequent reaction with cerium triflate (molar ratio $2: 1$ ) led to the extremely air-sensitive dark green anionic complex $\mathbf{8}$, which was oxidized in situ with silver iodide to give bis[1,3,6tris(trimethylsilyl)cyclooctatetraene]cerium(Iv) (9). This forms permanganate-colored crystals with a low melting point (m.p. $=38^{\circ} \mathrm{C}$ ), which are stable in air for a short period of time and very soluble in nonpolar solvents such as pentane, hexane, or toluene. Complex 9 can be vaporized without decomposition; in the El mass spectrum it exhibits the molecular peak with $14 \%$ relative intensity.

Deep purple single crystals of 9 were obtained from acetonitrile. The single-crystal X-ray structure analysis ${ }^{[17]}$ confirms the presence of a neutral cerium(IV) complex (Fig. 1). The two annulene rings are $\eta^{8}$-coordinated to the cerium atom. The $\mathrm{Ce} 1-\mathrm{C}$ distances range from 267.0 to $275.1 \mathrm{pm}$ and are comparable with those of related complexes. ${ }^{[10]}$ The two $\mathrm{C}_{8}$ rings in 9 are not coplanar. The ring centroid-Ce-ring centroid angle is
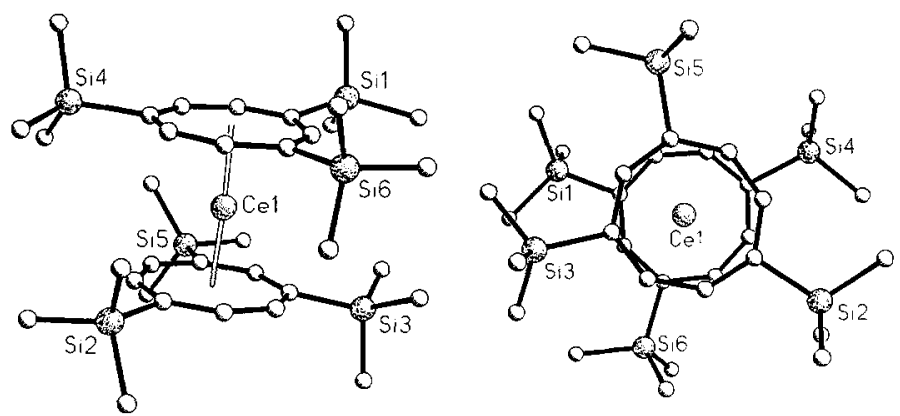

Fig. 1. Side view (left) and top view (right) of 9 ; mean bond lengths [pm] and bond angles ["]: Ce $1-\mathrm{C}$ (mean) 270.4(7) (267.0(6)-275.1(7)), Ce 1-ring centroid 197.6(6) and 197.7(6); ring centroid-Ce $t$-ring centroid 176.1(3).

$176.1^{\circ}$ and is thus almost identical with the corresponding value in the anionic $\mathrm{Yb}^{11}$ derivative $\left[\mathrm{Yb}\left(\mathrm{C}_{8} \mathrm{H}_{8}\right)_{2}\right]^{2-}\left(177^{\circ}\right) .^{[18]}$ The nonlinear coordination of the metal atom in 9 is probably due to steric reasons. The more open side of 9 is the one at which the $\mathrm{Me}_{3} \mathrm{Si}$ groups of $\mathrm{Si} 1$ and $\mathrm{Si} 3$ (Fig. 1 right) are closest to each other $(521.4 \mathrm{pm})$. In comparison, for example, the $\mathrm{Si} 2 \cdots \mathrm{Si} 4$ distance on the closed side is $30 \mathrm{pm}$ longer. All other $\mathrm{Si} \cdots \mathrm{Si}$ distances range from 570 to $590 \mathrm{pm}$.

The high solubility of 9 can be attributed to the $\mathrm{Me}_{3} \mathrm{Si}$ groups, which interlock like a set of cog wheels (Fig. 2) and surround the metal atom with an organic shell.

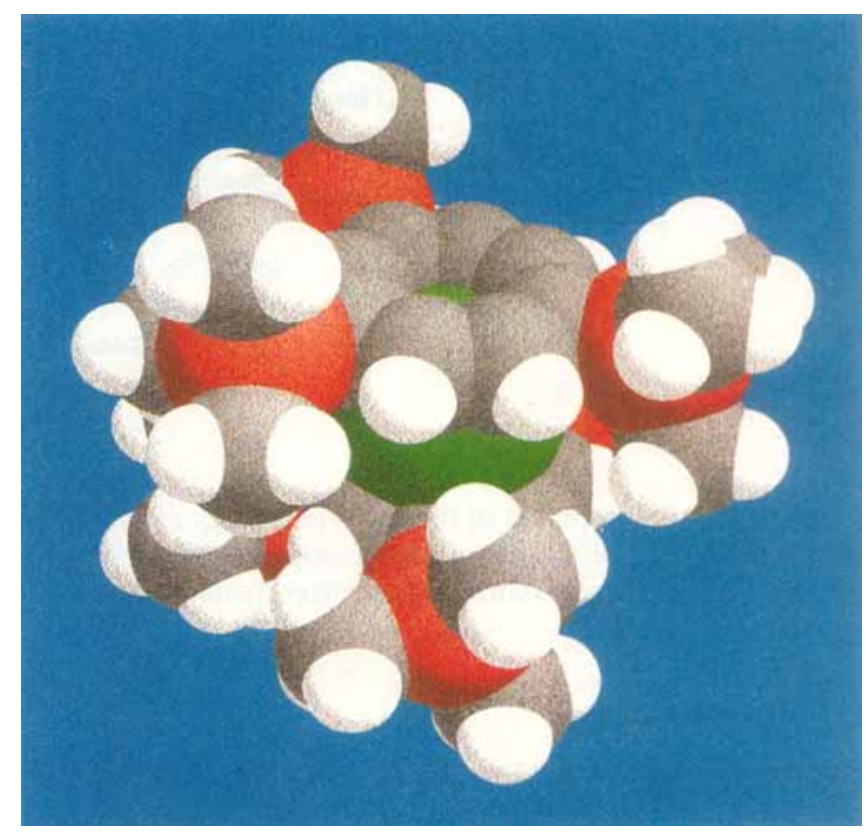

Fig. 2. Space-filling model of 9 .

In order to determine the rotation barrier in sandwich complexes with the 1,3,6-( $\left.\mathrm{Me}_{3} \mathrm{Si}\right)_{3} \mathrm{C}_{8} \mathrm{H}_{5}^{2-}$ ligand, the uranium complex 10, analogous to 9 , was synthesized and its variable-temperature ${ }^{1}$ H NMR spectra were analyzed. Dark green $\mathbf{1 0}$ is readily obtained from the reaction of anhydrous uranium tetrachloride with two equivalents of 7 . This complex is also stable in air for a short period of time, whereas the unsubstituted parent compound $\left[\mathrm{U}\left(\mathrm{C}_{8} \mathrm{H}_{8}\right)_{2}\right]$ is highly pyrophoric. ${ }^{[19]}$ In the EI mass spectrum of 10 the molecular peak appears with $100 \%$ relative intensity. The energy barrier for the rotation of the two sub- 


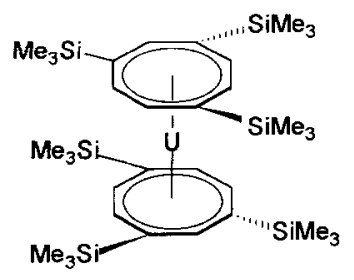

10 stituted cyclooctatetraene rings can be determined $\left(\Delta G^{*}\right.$ $=18 \mathrm{~kJ} \mathrm{~mol}^{-1}$ ) from the coalescence of the $\mathrm{SiMe}_{3}$ signals in the temperature-dependent ${ }^{1} \mathrm{H}$ NMR spectrum of $\mathbf{1 0}$.

This value seems surprisingly low when compared with the rotation barrier of $34.7 \mathrm{~kJ} \mathrm{~mol}^{-1}$, which was determined by Streitwieser et al. for bis[1,4-bis(tert-butyl)cyclooctatetraene]uranium. ${ }^{[20]}$ Our explanation for this difference is that the substituted cyclooctatetraene ligands in $\mathbf{1 0}$ do not undergo a complete rotation but only oscillate. The same phenomenon was already detected by NMR spectroscopy by Okuda for $1,1^{\prime}, 2,2^{\prime}, 4,4^{\prime}$-hexakis(trimethylsilyl)ferrocene. ${ }^{[21,22]}$ The rotation barrier here is as high as that for $1,1^{\prime}, 3,3^{\prime}$-tetrakis(trimethylsilyl)ferrocene $\left(11.0 \mathrm{~kJ} \mathrm{~mol}^{-1}\right)$, which contains only four silyl groups.

The ready availability of soluble cerium(IV) complexes opens up very promising perspectives for novel electron transfer reactions. The redox reaction of $\mathbf{5}$ with cobaltocene serves as a first example. This reduction leads to the saltlike $\mathrm{Ce}^{\mathrm{III}}$ compound $\mathbf{1 1}$, in which both the cation and the anion are sandwich complexes. The green cobaltocenium salt 11 can be characterized spectroscopically without any problems.

\section{$\left[\left\{1,4-\left(\mathrm{Me}_{3} \mathrm{Si}\right)_{2} \mathrm{C}_{8} \mathrm{H}_{6}\right\}_{2} \mathrm{Ce}\right]+\left[\left(\mathrm{C}_{5} \mathrm{H}_{5}\right)_{2} \mathrm{Co}\right]$}

5

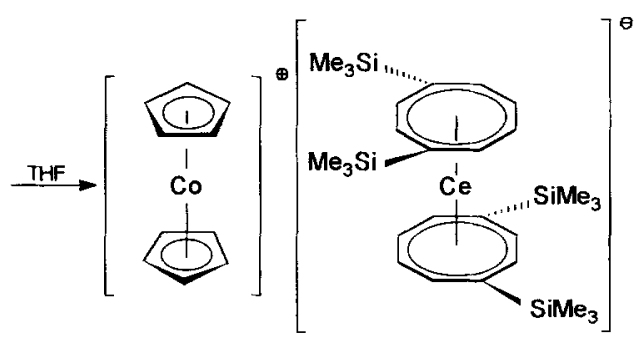

11

The further development of the redox chemistry of 5 and 9 as well as possible applications of these complexes as soluble oxidizing agents in organic synthesis are currently under investigation.

\section{Experimental Procedure}

Synthesis and characterization: All work was carried out under a purified $\mathrm{N}_{2}$ atmosphere.

5: 2 (6.1 g. $24.4 \mathrm{mmol})$ [14] in THF $(50 \mathrm{~mL})$ was treated dropwise with $n$ BuLi $(48.8 \mathrm{mmol})$ at $-30 \mathrm{C}$. The mixture was allowed to warm to room temperature and stirred for $1 \mathrm{~h}$. To the resulting brown solution was added a suspension of $\mathrm{CeCl}_{3}$ $\{3.0 \mathrm{~g}, 12.2 \mathrm{mmol}\}[23]$ in THF $(30 \mathrm{~mL})$ at $0^{\circ} \mathrm{C}$. This led to a dark green solution which wat again allowed to warm to room temperature, stirred for two days. filtered through a layer of Celite, and the filtrate was treated with AgI $(5.6 \mathrm{~g}, 24.0 \mathrm{mmol})$. In addition to the formation of elemental $\mathrm{Ag}$, the solution immediately turned deep purple. The reaction mixture was stirred for $12 \mathrm{~h}$ with exclusion of light, and evaporated. The residue was treated with hexane $(50 \mathrm{~mL})$, and carefully filtered. Removal of the solvent under vacuum afforded $5(3.1 \mathrm{~g}, 40 \%)$ as a deep purple . oily product. Correct elemental analysis: m.p. $226 \mathrm{C}$ (decomp), ${ }^{1} \mathrm{H} \mathrm{NMR}(250.1 \mathrm{MHz}$, $\left.\mathrm{C}_{\mathrm{t}} \mathrm{D}_{6}\right): \delta=6.13\left(\mathrm{~m},{ }^{3} \mathrm{~J}(\mathrm{H}, \mathrm{H})=7 \mathrm{~Hz}, 2 \mathrm{H}\right.$, ring- $\left.\mathrm{H}\right), 5.98(\mathrm{~m}, 2 \mathrm{H}$, ring- $\mathrm{H}), 5.92(\mathrm{~m}$, ${ }^{3} J(\mathrm{H}, \mathrm{H})=11 \mathrm{~Hz},{ }^{4} J(\mathrm{H}, \mathrm{H})=3 \mathrm{~Hz}, 2 \mathrm{H}$, ring-H $), 5.88\left(\mathrm{~m},{ }^{3} J(\mathrm{H}, \mathrm{H})=7 \mathrm{H} z, 2 \mathrm{H}\right.$, ring$\mathrm{H}), 5.83(\mathrm{~m}, 2 \mathrm{H}$, ring- $\mathrm{H}), 5.72\left(\mathrm{~m},{ }^{3} J(\mathrm{H}, \mathrm{H})=11 \mathrm{~Hz},{ }^{4} J(\mathrm{H}, \mathrm{H})=3 \mathrm{~Hz} .2 \mathrm{H}\right.$, ring-H), 0.08 (s. $\left.18 \mathrm{H}, \mathrm{SiMe}_{3}\right), 0.07$ (s. $18 \mathrm{H}, \mathrm{SiMe}_{3}$ ): ${ }^{29} \mathrm{Si} \mathrm{NMR}\left(49.7 \mathrm{MH}\right.$, [D ${ }_{2}$ ]loluene): $\delta=-5.44(\mathrm{~s}),-5.43(\mathrm{~s}) ; \mathrm{MS}(\mathrm{EI}): m_{i}:: 636\left(\left[\mathrm{M}^{+}\right], 6 \%\right), 388\left(\left[\mathrm{Ce}\left[\mathrm{C}_{8} \mathrm{H}_{6}(1,4-\right.\right.\right.$ $\left.\left.\left.\mathrm{SiMe}_{3}\right)_{2}^{\dagger}\right] .52 \%\right) .249\left(\left[\mathrm{C}_{8} \mathrm{H}_{6}\left(1,4-\mathrm{SiMe}_{3}\right)_{2}^{+}\right], 4 \%\right) .73\left(\left[\mathrm{SiMe}_{3}^{+}, 100 \%\right) ; \mathrm{IR}(\mathrm{KBr}\right.$. pure substance): $\tilde{\mathrm{v}}\left[\mathrm{cm}^{-1}\right]=1578 \mathrm{~m}, 1310 \mathrm{~m}, 1249 \mathrm{vs}, 1102 \mathrm{~s} .1080 \mathrm{~m}, 1004 \mathrm{~m}, 975$ m, $929 \mathrm{~s}, 880 \mathrm{~s}, 839 \mathrm{vs}, 751 \mathrm{~s}, 715 \mathrm{~m}, 633 \mathrm{~s}, 565 \mathrm{~m}, 511 \mathrm{~m}, 447 \mathrm{~m}, 372 \mathrm{~m}$

6: $n \mathrm{BuLi}(239.6 \mathrm{mmol})$ was added dropwise to a solution of $2(30 \mathrm{~g}, 119.8 \mathrm{mmol})$ [14] in THF $(200 \mathrm{~mL})$ at $-30^{\circ} \mathrm{C}$. Subsequently the solution was allowed to warm to room temperature and stirred for a further $12 \mathrm{~h}$. The resulting deep brown solution was added dropwise to a solution of $\mathrm{Me}_{3} \mathrm{SiCl}(26.0 \mathrm{~g}, 239.6 \mathrm{mmol})$ in $\mathrm{Et}_{2} \mathrm{O}(150 \mathrm{~mL})$ at $-10 \mathrm{C}$. The mixture was allowed to react at $-10^{\circ} \mathrm{C}$ for $10 \mathrm{~min}$. then for $12 \mathrm{~h}$ at room temperature. filtered carefully, and the filtrate was evaporated to dryness under vacuum. The crude product was treated with dry MeOH $(250 \mathrm{~mL})$ and filtered while hot to remove the insoluble material. Cooling to $-20^{\circ} \mathrm{C}$ afforded pale yellow, needlelike crystals of $6(24.7 \mathrm{~g}, 52 \%)$, m.p. $87^{\circ} \mathrm{C}$. correct elemental analysis: ${ }^{1} \mathrm{H}$ NMR $\left(\mathrm{CDCl}_{3}, 400.1 \mathrm{MHz}\right): \delta=6.15\left(\mathrm{ddd},{ }^{3} J(\mathrm{H}, \mathrm{H})=9 \mathrm{~Hz},{ }^{4} J(\mathrm{H}, \mathrm{H})=1 \mathrm{~Hz}\right.$, ${ }^{4} J(\mathrm{H}, \mathrm{H})=1 \mathrm{~Hz}, 1 \mathrm{H}$, ring $\left.-\mathrm{H}\right), 5.51\left(\mathrm{dd},{ }^{3} J(\mathrm{H}, \mathrm{H})=11 \mathrm{~Hz},{ }^{3} J(\mathrm{H}, \mathrm{H})=9 \mathrm{~Hz}, 1 \mathrm{H}\right.$, ring-H), $5.43\left(\mathrm{dd},{ }^{3} J(\mathrm{H}, \mathrm{H})=13 \mathrm{~Hz},{ }^{4} J(\mathrm{H}, \mathrm{H})=1 \mathrm{~Hz}, 1 \mathrm{H}\right.$, ring- $\left.\mathrm{H}\right), 5.22$ (ddd, ${ }^{3} J(\mathrm{H} . \mathrm{H})=11 \mathrm{~Hz},{ }^{4} J(\mathrm{H} . \mathrm{H})=1 \mathrm{~Hz},{ }^{4} J(\mathrm{H}, \mathrm{H})=1 \mathrm{~Hz}, 1 \mathrm{H}, \quad$ ring- $\left.\mathrm{H}\right), 5.18 \quad(\mathrm{ddd}$ ${ }^{3} J(\mathrm{H}, \mathrm{H})=13 \mathrm{~Hz},{ }^{4} J(\mathrm{H}, \mathrm{H})=1 \mathrm{~Hz},{ }^{5} J(\mathrm{H}, \mathrm{H})=1 \mathrm{~Hz}, 1 \mathrm{H}, \quad$ ring- $\left.\mathrm{H}\right), 4.27$ (ddd ${ }^{3} J(\mathrm{H}, \mathrm{H})=9 \mathrm{~Hz},{ }^{3} J(\mathrm{H}, \mathrm{H})=9 \mathrm{~Hz},{ }^{4} J(\mathrm{H}, \mathrm{H})=1 \mathrm{~Hz}, 1 \mathrm{H}$, ring- $\left.\mathrm{H}\right), 0.10$ (s. $9 \mathrm{H}$, $\left.\mathrm{SiMe}_{3}\right), 0.04\left(\mathrm{~s}, 9 \mathrm{H}, \mathrm{SiMe}_{3}\right), 0.03\left(\mathrm{~s}, 9 \mathrm{H}, \mathrm{SiMe}_{3}\right),-0.03\left(\mathrm{~s}, 9 \mathrm{H}, \mathrm{SiMe}_{3}\right) ;{ }^{13} \mathrm{C} \mathrm{NMR}$ $\left(\mathrm{CDCl}_{3}\right): \delta=145.6\left(\mathrm{~s}\right.$, ring-C), $143.1\left(\mathrm{t},{ }^{1} J\left({ }^{13} \mathrm{C},{ }^{29} \mathrm{Si}\right)=66 \mathrm{~Hz}\right.$, ring-C), $133.1(\mathrm{~s}$. ring-C) $131.0(\mathrm{~s}$, ring-C), 129.0 (s. ring-C). 126.2 (s, ring-C). 37.4 (t ${ }^{1} J\left({ }^{13} \mathrm{C}_{.}{ }^{29} \mathrm{Si}\right)=43 \mathrm{H}$, ring-C $), 29.9\left(\mathrm{t},{ }^{1} J\left({ }^{13} \mathrm{C},{ }^{29} \mathrm{Si}\right)=53 \mathrm{H}\right.$, ring-C $),-1.3(\mathrm{t}$, $\left.{ }^{1} J\left({ }^{13} \mathrm{C},{ }^{29} \mathrm{Si}\right)=52 \mathrm{~Hz}, \mathrm{SiMe}_{3} \mathrm{C}\right),-1.4\left(\mathrm{t} .{ }^{1} J\left({ }^{13} \mathrm{C},{ }^{29} \mathrm{Si}\right)=52 \mathrm{~Hz}, \mathrm{SiMe}_{3} \mathrm{C}\right),-1.5(\mathrm{t}$, $\left.{ }^{1} J\left({ }^{13} \mathrm{C}_{2}{ }^{29} \mathrm{Si}\right)=52 \mathrm{~Hz}, \mathrm{SiMe}_{3} \mathrm{C}\right),-3.1\left(\mathrm{t},{ }^{1} J\left({ }^{13} \mathrm{C},{ }^{29} \mathrm{Si}\right)=51 \mathrm{~Hz}, \mathrm{SiMe}_{3} \mathrm{C}\right) ;{ }^{29} \mathrm{Si}$ NMR $\left(\mathrm{CDCl}_{3}\right): \delta=-5.3$ (s. SiMe $\left.\mathrm{Si}_{3}\right) \cdot 2.0\left(\mathrm{~s}_{,} \mathrm{SiMe}_{3}\right) \cdot 2.4\left(\mathrm{~s}_{1} \mathrm{SiMe}_{3}\right), 2.6\left(\mathrm{~s} . \mathrm{SiMe}_{3}\right)$ MS (El): $m: z: 394\left(\left[M^{\dagger}\right], 34 \%\right), 321\left(\left[M-\mathrm{SiMe}_{3}^{+}\right], 60 \%\right), 233\left(\left[M-2 \mathrm{SiMe}_{3} \mathrm{CH}_{3}^{\dagger}\right]\right.$, $54 \%) .73\left(\left[\mathrm{SiMe}_{3}^{+}\right], 100 \%\right) ; \mathrm{IR}(\mathrm{KBr}, \mathrm{Nujol}): \ddot{i}\left[\mathrm{~cm}^{-1}\right]=1578 \mathrm{~m}, 1310 \mathrm{~m}, 1249 \mathrm{vs}$, $1102 \mathrm{~s}, 1080 \mathrm{~s}, 1004 \mathrm{~m}, 975 \mathrm{~m} .929 \mathrm{~s}, 880 \mathrm{~s} .839$ vs. 751 s. $715 \mathrm{~s} .686 \mathrm{s.} 633 \mathrm{~s}, 565 \mathrm{~m}$, $511 \mathrm{~m}, 447 \mathrm{~m}, 372 \mathrm{~m}$.

$7: 6(2.5 \mathrm{~g}, 6.3 \mathrm{mmol})$ and $\mathrm{KH}(0.8 \mathrm{~g} .20 .0 \mathrm{mmol})$ were heated under reflux in THF $(50 \mathrm{~mL})$ for 2 days. Subsequently, excess $\mathrm{KH}$ was filtered off. the orange solution evaporated to dryness, and the residue taken up in hexane $(40 \mathrm{~mL})$ and stirred for for $3 \mathrm{~h}$. The solid precipitate was separated and dried under vacuum. A white, microcrystalline powder $7(1.57 \mathrm{~g}, 37 \%)$ was obtained. Correct elemental analysis: m.p. 247 C (decomp); ${ }^{1}$ H NMR $\left(250.1 \mathrm{MHz},\left[\mathrm{D}_{\mathrm{s}}\right] \mathrm{THF}\right): \delta=6.39(\mathrm{~m}, 1 \mathrm{H}$, ring-H). $6.34(\mathrm{~m}, 1 \mathrm{H}$, ring- $\mathrm{H}), 6.30(\mathrm{~m}, 1 \mathrm{H}$, ring- $\mathrm{H}), 6.23(\mathrm{~m}, 1 \mathrm{H}$, ring- $\mathrm{H}), 6.18(\mathrm{~m}, 1 \mathrm{H}$. ring-H), $3.62(\mathrm{~m}, 12 \mathrm{H}, \mathrm{THF}), 1.79(\mathrm{~m}, 12 \mathrm{H}, \mathrm{THF}), 0.32\left(\mathrm{~s}, 18 \mathrm{H}, \mathrm{SiMe}_{3}\right), 0.27(\mathrm{~s}$, $\left.9 \mathrm{H}, \mathrm{SiMe}_{3}\right) ;{ }^{29} \mathrm{Si} \mathrm{NMR}\left(\left[\mathrm{D}_{8}\right] \mathrm{THF}\right): \delta=-2.3(\mathrm{~s}),-3.2$ (s, half intensity); MS (EI): $m_{1}^{i z}: 320\left(\left[\mathrm{C}_{8} \mathrm{H}_{5}\left(\mathrm{SiMe}_{3}\right)_{3}^{+}\right] .8 \%\right), 247\left(\left[\mathrm{C}_{8} \mathrm{H}_{5}\left(\mathrm{SiMe}_{3}\right)_{2}^{+}\right], 42 \%\right), 73\left(\left[\mathrm{SiMe}_{3}^{+}\right]\right.$. $100 \%$ ); IR (KBr, Nujol): i[ $\left.\mathrm{cm}^{-1}\right]=1734 \mathrm{~m} .1532 \mathrm{~m} .1304,1240$ vs. $1216 \mathrm{~m}, 1081$ vs, 1046 vs. $975 \mathrm{~s}, 924 \mathrm{~m} .889 \mathrm{~m} .870 \mathrm{~s} .824$ vs. 740 vs. $672 \mathrm{~m}, 633 \mathrm{~m} .567 \mathrm{~m}, 511 \mathrm{~m}$. 9: $7(2.5 \mathrm{~g}, 3.6 \mathrm{mmol})$ in THF $(50 \mathrm{~mL})$ was treated with a suspension of $\mathrm{Ce}\left(\mathrm{O}_{3} \mathrm{SCF}_{3}\right)_{3}(1.1 \mathrm{~g}, 1.8 \mathrm{mmol})$ [24] in THF $(30 \mathrm{~mL})$ at $0 . \mathrm{C}$ and stirred. The solution turned bright green. Subsequently, the mixture was allowed to react for at further $12 \mathrm{~h}$ under reflux, then $\mathrm{AgI}(0.9 \mathrm{~g} .3 .8 \mathrm{mmol})$ was added at room temperaturc, which caused an immcdiate color change to purple. After stirring the mixture for $1 \mathrm{~h}$ with exclusion of light, the solvent was evaporated, the residuc taken up in hexane $(50 \mathrm{~mL})$ and filtered. The filtrate was evaporated to dryness and the residue was treated with MeCN $(50 \mathrm{~mL})$. Crystallization at room temperature afforded 9 $(0.5 \mathrm{~g}, 33 \%)$ as a microcrystalline, deep purple solid. Correct elemental analysis. m.p. $38 \mathrm{C} ;{ }^{1} \mathrm{H}$ NMR $\left(250.1 \mathrm{MHz}, \mathrm{C}_{6} \mathrm{D}_{6}\right): \delta=6.43\left(\mathrm{~d},{ }^{3} J(\mathrm{H} . \mathrm{H})=12 \mathrm{~Hz}, 4 \mathrm{H}\right.$, ring $\mathrm{H}), 6.00\left(\mathrm{~d},{ }^{3} J(\mathrm{H} . \mathrm{H})=12 \mathrm{~Hz} .4 \mathrm{H}\right.$, ring-H), $5.61(\mathrm{~s}, 2 \mathrm{H}$, ring- $\mathrm{H}), 1.11(\mathrm{~s}, 18 \mathrm{H}$. $\left.\mathrm{SiMe}_{3}\right), 0.99\left(\mathrm{~s}, 36 \mathrm{H}, \mathrm{SiMe}_{3}\right) ;{ }^{29} \mathrm{Si} \mathrm{NMR}\left(\mathrm{C}_{6} \mathrm{D}_{6}\right): \delta=-1.74(\mathrm{~s}),-3.09$ (s, half intensity); MS (EI): $m_{i z}: 780\left(\left[\mathrm{M}^{+}\right], 14 \%\right), 708\left(\left[\mathrm{M}-\mathrm{SiMe}_{3}^{+}\right], 2 \%\right), 460$ $\left(\left[\mathrm{CeC}_{8} \mathrm{H}_{5}\left(\mathrm{SiMe}_{3}\right)_{3}^{+}\right], 100 \%\right), 386\left(\left[\mathrm{CeC}_{4} \mathrm{H}_{5}\left(\mathrm{SiMe}_{3}\right)_{2}^{+}\right], 8 \%\right) .73\left(\left[\mathrm{SiMe}_{3}^{+}\right] .38 \%\right)$. 10: $\mathrm{UCl}_{4}(0.7 \mathrm{~g}, 1.8 \mathrm{mmol})$ [25] in THF $(30 \mathrm{~mL})$ was added to a solution of $7(2.5 \mathrm{~g}$. $3.6 \mathrm{mmol})$ in THF $(50 \mathrm{~mL})$ at $0^{\circ} \mathrm{C}$. The solution was then stirred for $3 \mathrm{~h}$ at room temperature, concentrated, treated with hexane $(30 \mathrm{~mL})$, and stirred for a further $12 \mathrm{~h}$. Subsequently, the mixture was filtered while hot and concentrated to $10 \mathrm{~mL}$. Cooling to $-20 \mathrm{C}$ afforded green crystals of $10(0.4 \mathrm{~g}, 28 \%)$. Correct elemental anaiysis; m.p. $110^{\circ} \mathrm{C}$ (decomp); ${ }^{1} \mathrm{H}$ NMR $\left(250.1 \mathrm{MHz},\left[\mathrm{D}_{\mathrm{H}}\right] \mathrm{THF}\right): \delta=0.03(\mathrm{~m}$. $10 \mathrm{H}$, ring-H), -7.30 (br. s, $\left.36 \mathrm{H}, \mathrm{SiMe}_{3}\right),-9.10\left(\mathrm{~s}, 18 \mathrm{H}, \mathrm{SiMe}_{3}\right):{ }^{29} \mathrm{Si} \mathrm{NMR}$ $\left(\left[\mathrm{D}_{4}\right] \mathrm{THF}\right): \delta=-120.7$ (s): MS (El): $m / z: 878\left(\left[\mathrm{M}^{+}\right], 100 \%\right), 806\left(\left[\mathrm{M}^{+}-\mathrm{SiMe}_{3}\right]\right.$. $3 \%), 732\left(\left[M^{+}-2 \mathrm{SiMe}_{3}\right], 5 \%\right), 558\left(\left[\mathrm{UC}_{8} \mathrm{H}_{5}\left(\mathrm{SiMe}_{3}\right)_{3}^{+}\right], 51 \%\right), 73\left(\left[\mathrm{SiMe}_{3}^{+}\right]\right.$. $44 \%$ ); IR (KBr, Nujol): i $\left[\mathrm{cm}^{-1}\right]=1260 \mathrm{vs}, 1249$ s. $1090 \mathrm{vs}, 1019 \mathrm{vs}, 836 \mathrm{~s}, 801 \mathrm{vs}$. $747 \mathrm{~m}, 638 \mathrm{~m}$.

11: $5(2.0 \mathrm{~g}, 3.1 \mathrm{mmol})$ and $\mathrm{Cp}_{2} \mathrm{Co}(0.6 \mathrm{~g}, 3.1 \mathrm{mmol})[26]$ were dissolved in THF $(40 \mathrm{~mL})$ and stirred for $3 \mathrm{~h}$. The initially purple solution turned red-brown. The mixture was filtered over a thin layer of Celite and the filtrate was evaporated to dryness. The residue taken up in hexane $(50 \mathrm{~mL})$, and the green precipitate was isolated and dried. Compound $11(0.2 \mathrm{~g} .7 \%)$ was obtained as a pyrophoric, extremely air-sensitve solid. Correct elemental analysis; m.p. $142{ }^{\circ} \mathrm{C}$ (decomp); ${ }^{1} \mathrm{H}$ $\left(250.1 \mathrm{MHz},\left[\mathrm{D}_{8}\right] \mathrm{THF}\right): \delta=6.21-5.79(\mathrm{~m}, 12 \mathrm{H}$, ring- $\mathrm{H}), 1.30\left(\mathrm{~s} .5 \mathrm{H}, \mathrm{C}_{5} \mathrm{H}_{5}\right), 1.05$ $\left(\mathrm{s}, 18 \mathrm{H}, \mathrm{SiMe}_{3}\right), 0.90\left(\mathrm{~s}, 5 \mathrm{H}, \mathrm{C}_{5} \mathrm{H}_{5}\right), 0.08$ (s, $\left.18 \mathrm{H}, \mathrm{SiMe}_{3}\right) ;{ }^{29} \mathrm{Si} \mathrm{NMR}\left(\left[\mathrm{D}_{8}\right] \mathrm{THF}\right)$ : $\delta=-2.4(\mathrm{~s}),-5.3(\mathrm{~s}) ; \mathrm{MS}(\mathrm{EI}): m_{i}=248\left(\left[\mathrm{C}_{8} \mathrm{H}_{6}\left(1.4-\mathrm{SiMe}_{3}\right)_{2}^{+}\right] .16 \%\right), 189$ $\left(\left[\mathrm{Co}\left(\mathrm{C}_{5} \mathrm{H}_{5}\right)^{+}{ }_{2}\right], 50 \%\right) .124\left(\left[\mathrm{Co}\left(\mathrm{C}_{5} \mathrm{H}_{5}\right)^{+}\right] .11 \%\right) .73\left(\left[\mathrm{SiMe}_{3}^{+}\right] .100 \%\right)$ : IR (KBr, Nujol): $:\left[\mathrm{cm}^{-1}\right]=1413 \mathrm{~m}, 1306 \mathrm{~m}, 1261 \mathrm{vs}, 1248 \mathrm{~m} .1092 \mathrm{vs}, 1037 \mathrm{vs}, 980 \mathrm{~m}, 937$ m. $861 \mathrm{~m}, 836 \mathrm{~s}, 800 \mathrm{vs}, 750 \mathrm{~m}, 688 \mathrm{~m}, 637 \mathrm{~m}, 436 \mathrm{~m}$. 
[1] H. Schumann, Angew. Chem. 1984. 96, 475; Angew. Chem. Hnt. Ed. Engt 1984 23. 484

[2] D. A. Johnson. Adv. Inorg. Chem. Radiochem. 1977, 20, 1

[3] B. L. Kalsotra, S. P. Anand, R. K. Multani, B. D. Jain, J. Organomet. Chem $1971,28,87$.

[4] B. L. Kalsotra, R. K. Multini, B. D. Jain, J. Inorg. Nucl. Chem. 1972, 34 2265.

[5] S. Kapur, B. L. Kalsotra, R. K. Multani. B. D. Jain. J. Inorg. Nucl. Chem 1973. 35. 1689 .

[6] S. Kapur, B. L. Kalsotra, R. K. Multani, J. Inorg. Nucl. Chem. 1973, 35. 3966 .

[7] G. B. Deacon. T. D. Tuong. D. G. Vince. Polyhedron 1983, 2, 969

[8] N. Rösch, A. Streitweiser, J. Am. Chem. Soc. 1983, 2, 969: N. Rösch. Inorg. Chim, Acta 1984, 94, 297.

[9] M. Dolg, P. Fulde, W. Küchle, C.-S. Neumann, H. Stoll, J. Chem. Phys. 1991 94. 3011 .

[10] T. R. Boussie. D. C. Eisenberg, J. Rigsbee, A. Streitwieser. A. Zalkin, Organometallics 1991. 10, 1922.

[11] A. Greco. S. Cesca, G. Bertolini, J. Organomet. Chem. 1976, 113, 321.

[12] M. F. Lappert, A. Singh, J. L. Atwood, W. E. Hunter, J. Chem. Soc. Chem. Conmmin. 1981, 1190.

[13] M. F. Lappert, A. Singh. J. L. Atwood, W. E. Hunter, J. Chem. Soc. Chem Commun. 1981, 1191

[14] N. C. Burton. F. G. N. Cloke, P. B. Hitchcock, H. C. de Lemos, A. A. Sameh. J. Chum. Soc. Chem. Commun. 1989. 1463.

[15] After the completion of our work compound 6 was also published by Cloke et al.: N. C. Burton, F. G. N. Cloke, S. C. P. Joseph, H. Karamallakis, A. A. Sameh. J. Organomet. Chem. 1993, 462,39.

[16] P. Jutzi. R. Sauer, J. Organomet. Chem. 1973, 50, C29.

[17] Crystal data of 9: $\left[\left(\mathrm{Me}_{3} \mathrm{Si}_{3} \mathrm{C}_{8} \mathrm{H}_{4}\right]_{2} \mathrm{Ce}, M=781.51\right.$, orthorhombic, space group Phat $, \quad a=2232.2(4), \quad b=1647.6(3), c=1132.3(2) \mathrm{pm}, \quad V=$ $4.163(1) \mathrm{nm}^{3}, Z=4, \quad \rho_{\text {calcd }}=1.247 \mathrm{Mgm}^{-3}, F(000)=1640, \quad \lambda=71.073 \mathrm{pm}$ $T=-120$ C. $\mu\left(\mathrm{Mo}_{\mathrm{k},}\right)=1.286 \mathrm{~mm}^{-1}$. crystal dimensions : $0.6 \times 0.6 \times 0.4 \mathrm{~mm}$. $4<20<50 ;$ of 5491 measured reflections, 5084 were independent and 5080 were used for the refinement of 388 paramters: maximum residual electron density: $1572 \mathrm{enm}^{-3}, R 1(F>4 \sigma(F))=0.039, \mu R 2=0.115$ (all data) with $R 1=\Sigma|| F_{0}|-| F_{0}|/ \Sigma| F_{0} \mid$ and $\| R 2=\left(\sum w\left(F_{0}^{2}-F_{0}^{2}\right)^{2} / \Sigma w\left(\mathrm{~F}_{0}^{2}\right)^{2}\right)^{0.5}$. The data were collected on a Stoe-Huber diffractometer. The intensity measurement were carried out on a rapidly cooled crystal in the oil drop [26] by the $2 \theta / \omega$ method. Semiempirical absorption corrections were carried out on all data. The strueture was solved by Patterson and Fourier methods (SHELXS-90) [27] and refined with the least squares method on $F^{2}[28]$. The refinement of the inversion twin parameter [29] $(x=0.00$ (2) for $x=0$ for the correct absolute structure and $x=+1$ for the inverted structure) confirmed the absolute structure of 9 . Further details of the crystal structure investigation are available on request from the Director of the Cambridge Crystallographic Data Centre. 12 Union Road. GB-Cambridge CB2 $1 \mathrm{EZ}$ (UK), on quoting the full journal citation.

[18] S. A. Kinsley, A. Streitwieser, A. Zalkin, Acta Crsstallogr. Sect. C 1979, 35, 1068 .

[19] A. Sieitwieser. U. Müller-Westerhoff, J. Am. Chem. Soc. 1968, 90, 7364

[20] W. D. Luke. A. Streitwieser. J. Am. Chem. Soc. 1981, 103, 3241.

[21] J. Okuda, Top. Curr. Chem. 1992, 160, 97.

[22] J. Okuda, E. Herdtweck, Chem. Ber. 1988, 121, 1899.

[23] J. H. Freeman. M. L. Smith, J. Inorg. Nuct. Chem. 1958, 7, 224.

[24] F. E. Hahn, J. Mohr, Chem. Ber. 1990, 123, 481.

[25] J. A. Herrmann. J. F. Suttle, Inorg. Sinth. 1957, 5, 143.

[26] T. Kottke, D. Stalke, J. Appl. Crystallogr. 1993, 26, 615.

[27] G. M. Sheldrick. Acta Crystallogr. Sect. A 1990, 46, 467.

[28] G. M. Sheldrick, SHELXL-93, program for crystal structure refinement, Göttingen, 1993.

[29] H. D. Flack, Acta Cristallogr. Sect. A 1983, 39.876.

\section{Mixed-Valence, Tetranuclear Iron Chelate \\ Complexes as Endoreceptors: Charge Compensation Through Inclusion of Cations**}

Rolf W. Saalfrank, * Roman Burak, Alexandra Breit, Dietmar Stalke, Regine Herbst-Irmer, Jörg Daub, Michael Porsch, Eckhard Bill, Markus Müther, and Alfred X. Trautwein

\section{Dedicated to Professor Helmut Ringsdorf on the occasion of his 65th birthday}

An essential prerequisite for the rapid development of endohedral chemistry, that is chemistry within cages, is easy access to host molecules of variable internal diameter. ${ }^{[2]}$ In this context we have recently reported the tetranuclear adamantanoid $\mathrm{Fe}^{\mathrm{III}}$ spacer-complex $\left[\mathrm{Fe}_{4} \mathrm{~L}_{6}^{1}\right] 1$ 1. $^{[1]}$ Complex 1 is endowed with a substantial cavity, which should, in principle, be suitable for the uptake of guest molecules. Our attempts to obtain the spacerfree metallospherand core unit $\left[\mathrm{Fe}_{4} \mathrm{~L}_{6}^{2}\right]$ in analogous manner have thus far given rise to products which could not be characterized unambiguously.

In contrast, we have obtained for the first time, the tetranuclear, mixed-valence ammonium inclusion complexes $\left[\mathrm{NH}_{4} \subset \mathrm{Fe}_{4} \mathrm{~L}_{6}^{2}\right] 2$ and $\left[\mathrm{NH}_{4} \subset \mathrm{Fe}_{4} \mathrm{~L}_{6}^{3}\right] 3$ in a one-pot reaction. ${ }^{[3]}$ Complexes 2 and 3 are formed by spontaneous self-assembly ${ }^{[1,4-7]}$ from the reaction of dialkyl malonates with methyllithium/iron(II) chloride and oxalyl chloride at $-78^{\circ} \mathrm{C}$ in tetrahydrofuran, followed by workup with aqueous ammonium
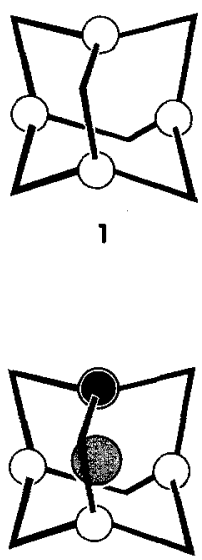

2,3
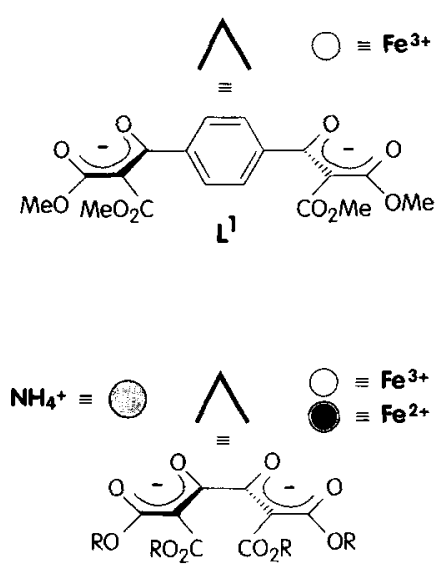

$L^{2}: R=M e ; L^{3}: R=E t$
[*] Prof. Dr. R. W. Saalfrank, Dr. R. Burak, Dipl.-Chem. A. Breit, Institut für Organische Chemie der Universität Erlangen-Nürnberg Henkestrasse 42, D-91054 Erlangen (FRG) Telefax: Int. code $+(9131) 85-6864$

Priv.-Doz. Dr. D. Stalke, Dr. R. Herbst-Irmer ${ }^{[+]}$ Institut für Anorganische Chemie der Universität Göttingen (FRG) Prof. Dr. J. Daub, Dipl.-Chem. M. Porsch ${ }^{1++}$ Institut für Organische Chemie der Universität Regensburg (FRG) Dr. E. Bill, Dipl.-Phys. M. Müther, Prof. Dr. A. X. Trautwein ${ }^{1+++1}$ Institut für Physik der Medizinischen Universität Lübeck (FRG)

$\left.{ }^{+}\right]$Single-crystal X-ray diffraction analyses.

$\left[{ }^{++}\right]$Electrochemistry.

$\left[{ }^{+++}\right]$Mössbauer spectra.

[**] "Adamantanoid" Chelate Complexes, Part 4. This work was supported by the Deutsche Forschungsgemeinschaft and by the Fonds der Chemischen Industrie. We thank Prof. Dr. F. Vögtle and Dr. S. Schuth, Universität Bonn, and Prof. Dr. K.-P. Zeller, Universität Tübingen for the measurement of the FAB mass spectra. Part 3: ref. [1]. 